\title{
Introduction: what is social in social entrepreneurship?
}

\section{Chris Steyaert and Daniel Hjorth}

This book investigates the social of social entrepreneurship: what is meant by connecting entrepreneurship with the social? How does the social make social entrepreneurship different from entrepreneurship, if at all? Is social entrepreneurship a new field within entrepreneurship research that needs its own theories and concepts? Or is it just an epitheton ornans and is it better to question any distinction between entrepreneurship and social entrepreneurship? Or, yet again, does the social appellation create new chances to probe into the sociality of entrepreneurship and into a (new) entrepreneuriality of society?

The title of this third Movements in Entrepreneurship book Entrepreneurship as Social Change - suggests a probing answer in the form of claiming a double sociality for entrepreneurship. Firstly, the title indicates that entrepreneurship is connected to social change and societal transformation. This is an observation, belief and concept that has become popular in the recent rise in interest in social entrepreneurship, which we take up to inspect critically, yet affirmatively: how is social change understood, imagined and practiced? By connecting entrepreneurship with social change, we believe the platform or the 'space' of entrepreneurship becomes disclosed as part of society (Steyaert and Katz, 2004; Hjorth and Steyaert, 2003) and we can grasp the chance to look into the multidiscursive construction of entrepreneurship beyond any economic or progress-instrumentalist reductionism. However, some contend that the emergence of social entrepreneurship brings along rather a return to economic and economizing discourse and an intensification of managerial logic. This book examines this claim more closely, asks whether this is an inevitable evolution and inquires what alternative turns or twists can be formulated and tried out: this book asks what people to come, what society to come is unimagined in this dominant approach to 'social entrepreneurship', and brings such examples to our readers.

Secondly, the title puts forward a concept of entrepreneurship that says that entrepreneurship is a process based on the course of social change. By conceiving entrepreneurship as social change, we believe a possibility is created to inquire into the social nature of entrepreneurship and to switch the 
all-too-familiar inclination of the field of entrepreneurship to return to a possessive individualism for a broader social science view (Swedberg, 1999) that conceives entrepreneurship through concepts of sociality such as relation, community, social cauldron, legitimacy, spatiality, resistance, citizenship and the public. Also an opportunity exists here to alter the disciplinary hierarchy that has favoured theories from economics and (individualist) psychology and to connect with concepts and notions of less frequently visited disciplines and theoretical domains (Steyaert, 2005). This book then combines and interweaves two beliefs we think the rise in interest in social entrepreneurship enables us to explore, which can help to move the entire field of entrepreneurship: entrepreneurship is a complex social-creative process that influences, multiplies, transforms, re-imagines and alters the outlook of the space of society in which it is at once grounded and contextualized.

As a work in the series Movements in Entrepreneurship, this book hopes to create some movement itself. At a moment when the interest in social entrepreneurship booms in media, education and politics and is well on its way to becoming the next fad in entrepreneurship studies and business schools, we believe it well timed to engage with an in-depth inquiry into the social aspects of entrepreneurship and the surprisingly entrepreneurial aspects of society, and well placed to make possible a movement that brings social entrepreneurship out of its endangered position of fashionable topic for philanthropists, pensioned CEOs equipped with problem-fixing managerial tools, education programmers and social change engineers. The movement that might become possible is one that makes entrepreneurship social: that is, one that enables us to imagine and invent new possibilities, to contribute to its heterogeneity and democratic spread in society, and to reach out for the well-being of all on this earth. The movement from 'social entrepreneurship' to 'making entrepreneurship social' requires us to leave fixed understandings of entrepreneurship behind and to release its multiple versions: the becoming social of entrepreneurship and the becoming entrepreneurial of the social. As social entrepreneurship is not yet a solidified signifier, it might be possible to rescue and make public some of the less evident meanings that otherwise might remain at the margins of the currently academic and popular discourse of social entrepreneurship. In that sense, we hope the book to be programmatic, not as a definite plan with distinctive steps, but in the etymological sense of the Greek programma, meaning 'a written public notice', stemming from prographein, 'to write publicly'. In that sense, with this book, social entrepreneurship becomes written in the public domain (see the contributions of O'Connor and Hjorth and Bjerke below) and can become envisioned as a 'public matter'.

The argument of this introductory chapter evolves as follows. First, we will situate the thematics of this book on entrepreneurship as social change in the light of the recent rise of the phenomenon of social entrepreneurship and the 
increased attention being given to it. We summarize the types of interventions this book aims for, which we find important to secure some of the promises at the margins of the current discourse of social entrepreneurship. The goal is to indicate how entrepreneurship might become social. Second, we will relate the social of entrepreneurship to the metaphor and idea of the earth as the space where the social is not only grounded and contextualized but also changed and transformed. We find the idea of the earth pertinent as it does not carve out the social as disconnected from nature and can allow us to conceive new - read entrepreneurial - versions and understandings of the social. Third, we will give a commentated overview of the first section of this book that comprises the range of conceptual explorations in relation to the emergence of interest in social entrepreneurship. We will travel - move - between a refreshing reading of the early Schumpeter and a rhetorical analysis of the current academic literature on social entrepreneurship, exploring in between four empirical studies that question narrow conceptions of social entrepreneurship and try to engage with new theoretical formulations. Fourth, we will introduce the second section of this book that presents several contextual examples of how entrepreneurship can create and shape social change, which illustrate that the richness of empirical research opens up our understanding of the sociality of entrepreneurship rather than keeping it limited or frozen. We will travel move - here between the countryside and nature, small towns and industrial districts and large cities and virtual spaces, indicating how social change has become initiated in various social settings, relationships and communities.

\section{SURPRISING THE ACADEMIC FIELD OF ENTREPRENEURSHIP?}

This book connects to the recent movement where social entrepreneurship has taken centre stage at a moment that the academic field of entrepreneurship is trying to emerge: as a distinctive field of research (Shane and Venkataraman, 2000), as a field that copes with its adolescence (Low, 2001), as a mature discipline that exploits its many years of exploratory research (Welsch and Liao, 2003) and as a field establishing a self-limiting discourse (Steyaert, 2005). There can be no sharper contrast than the one between the field of entrepreneurship contemplating how to limit and restrain itself and the unreserved and unrestrained enthusiasm for the phenomenon of social entrepreneurship that reminds one of the fervour and keenness of the newly arrived entrepreneurship scholars in the 1980s (Steyaert, 2005).

The 'rise' of the social entrepreneur (Leadbeater, 1997) and the 'spring' of social entrepreneurship seems unstoppable in academic attention, in practice

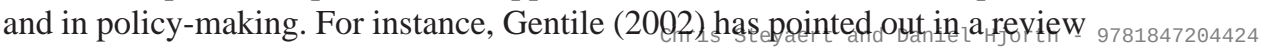


of the literature centred on the notion of 'social entrepreneur' that 75 per cent of those articles had been published in the last three years of a period of fifteen. Also social entrepreneurship should be more frequent than mainstream entrepreneurial activity, based on comparisons of socially entrepreneurial activity and total entrepreneurial activity presented in a UK-GEM study (Harding, 2004). In the US, non-profit organizations are the fastest-growing category of organizations (O'Connor, this volume). In policy-making and in political circles, social and civic entrepreneurs get central attention in those discussions on how to rebalance the role of government, businesses and civil society known as the so-called 'third way' (Giddens, 2000) and in discussions of welfare reform (Leadbeater, 1997).

This interest in social entrepreneurship seems to arrive simultaneously from very different corners of society with partly overlapping, partly different and even contradictory agendas: initiative-takers from voluntary, public and non-profit organizations look into methods and approaches that are mainstream in management and business life, while people from entrepreneurship and business life understand their (possible) impact on social welfare and civil society and take along their management experience and business methods and engage with philanthropic and social venturing or enter typically nonprofit areas, such as health and education. 'Social entrepreneurship', then, forms the 'hybrid' signifier and 'oxymoron' that can cover many diverse initiatives, oriented as an approach that can change welfare and social problems in the interfaces of the non-profit, public, voluntary, philanthropic and private sectors. Many initiatives have recently been rephrased as forms of social entrepreneurship (Thompson et al., 2000; Wallace, 1999) that previously were not seen as such and where the key actors have 'trouble' seeing themselves as 'entrepreneurs'.

Social entrepreneurship has had offspring in such diverse areas as the health sector (De Leeuw, 1999), the informal sector in the Third World (Morris, Pitt and Berton, 1996), ecology (Pastakia, 1998; Albrecht, 2002), non-governmental development organizations (Fowler, 2000), and various other cultural and social domains (Borzaga and Defourny, 2000; Dees, 1998). Both Borzaga and Defourny (2000) and Fowler (2000) suggest that these new forms of social entrepreneurship go beyond the current concept of the nonprofit sector and the social economy and recommend examining them as a new kind of social entrepreneurship and civic innovation. Such new initiatives can be seen as a form of R\&D in the welfare system as Leadbeater (1997, pp. 9-10) argued, since social enterprises 'operate as a kind of research and development wing of the welfare system, innovating new solutions to intractable social problems. [. . .] Most importantly they set in motion a virtuous circle of social capital accumulation. They help communities to build up social capital which gives them a better chance of standing on their own two feet' As a 
consequence the concept of social entrepreneurship figures in such nontraditional outlets of entrepreneurship research as: New Directions for Philanthropic Fundraising (Reis and Clohesy, 2001), the International Journal of Public Sector Management (Thompson, 2002), Public Administration Review (Eikenberry and Kluver, 2004), the International Journal of Nonprofit and Voluntary Sector Marketing (Mort, Weerawardena and Carnegie, 2003) and the Journal of Third World Studies (Najafizadeh and Mennerick, 2003).

Many questions emerge, when analyzing the upcoming social entrepreneurship movement, around how the field of entrepreneurship is currently considering it 'now a part of the mainstream' (Stevenson, 2004, p. 11). Has the academy of entrepreneurship slightly been surprised by this emergent interest? Can we assume this is rather and just a trend that will as quickly pass as it came along or at least quickly settle itself in the comfortable home of the maturing entrepreneurship field without asking too many disruptive questions? Or should we believe that the attention that social entrepreneurship provokes can form a line of flight that can destabilize this urge for established maturity and even pose new questions to the field of entrepreneurship that it is otherwise likely to exclude from its agenda, in its desperation to become that distinctive field? There are indeed some signs that indicate that the interest and activity around social entrepreneurship in many ways has taken the academy of entrepreneurship by surprise.

A first sign is that the academic entrepreneurship literature had been rather silent on social entrepreneurship for quite some time. Social entrepreneurship has never been a thematic section or even a chapter in the edited review books that regularly probe the 'state of the art' of the field (see Kent et al., 1982; Sexton and Smilor, 1986; Sexton and Kasarda, 1992; Sexton and Smilor, 1997; Sexton and Landström, 2000; Acs and Audretsch, 2003), and it has hardly been mentioned as a 'theme to watch out for' in the numerous review articles that look into future trends of the entrepreneurship field (see for example, Davidsson, Low and Wright, 2001; Grant and Perren, 2002; Busenitz et al., 2003). It is not an exaggeration to say that social entrepreneurship has been mostly neglected in the literature on entrepreneurship and has mainly been given the attention by scholars that typically do not belong to the core contributors of this field. For instance, Defourny (2000, p. 11) suggested that social enterprises might be seen 'as the expression of a new entrepreneurship', which is a claim well worth looking at more closely, but it is only slowly taken up by entrepreneurship scholars. That entrepreneurship scholars have started to follow this trend is illustrated by two special issues on social entrepreneurship, one published in the International Journal of Entrepreneurship Education (edited by Kourilsky and Walstad, 2004) and one on in the Journal of World Business (edited by Christie and Honig, 2006). Also an edited volume on 'The Way Ahead' for entrepreneurship by Welsch (2004) contains a small section 
on 'social entrepreneurship' (besides the usual themes of processes, technology, types, education), with two articles on community-based enterprises (Kuhns, 2004) and distressed inner cities (Fairchild and Greene, 2004). Social entrepreneurship is considered a new branch in the early stage of its development, figuring next to other branches such as family business, corporate entrepreneurship and entrepreneurship in the arts. As the definitions, associations, and academic treatments of social entrepreneurship are in their early stages, it is considered 'a cluster', characterized by its ideas 'being few in number, disorganized, ill-defined, and without significant academic theory' (Welsch and Maltarich, 2004, p. 60).

A second sign is that the entrance of social entrepreneurship is not announced with a little, modest knock on the door of the entrepreneurship field, asking permission for some empirical attention. The arrival of social entrepreneurship on the academic scene is rather loud and seems to be about big money. For instance, benevolent donations of entrepreneurs like Jeff Skoll to set up a social entrepreneurship research centre in the range of 4.4 million pounds to the Said Business School of Oxford University, did not go unenvied (and without resistance behind the scenes) by other business schools. Social entrepreneurship seems to come with large ambitions and heroism (see O'Connor, this volume). With unprecedented speed, social entrepreneurship courses have entered the programmes of top-tier business schools in the US (such as Harvard, Duke, Columbia and so on) and Europe (London and Said Business School).

Third, given the considerable disconnect between the 'core establishment' of entrepreneurship scholars and the 'new scholarship' of social entrepreneurship, social entrepreneurship might evolve relatively independently of the ongoing developments in the 'main' field of entrepreneurship or even try to establish itself as a 'separate' domain. In such a scenario, it is not unlikely that the scholarly coverage of social entrepreneurship might repeat the history of the academic entrepreneurship literature. For instance, there is a considerable concurrence between the emphasis on case studies, short stories and best practices examples of social entrepreneurship and their widespread use in the early entrepreneurship literature of the 1980s. One can notice a similar lamenting on the lack of clear definitions, generalizable models and theories. For instance, Thompson (2002, p. 412) observes with regard to the increasing use of the term social entrepreneurship that 'its meaning is not widely understood'. Another example is that the tendency to individualize the process of entrepreneurship, which was strongly rejected in entrepreneurship studies (see Gartner, 1988), reappears, and entrepreneurship becomes reduced to the study of the lone social entrepreneur. For instance, Drayton (2002) revisits the question 'who is the social entrepreneur?' and many of his illustrations of social entrepreneurship are stories of persons highlighting their skills and motivation 
(Roberts and Woods, 2005). Another parallel is that by placing it in the business schools, the 'ownership' of entrepreneurship is emphasized as falling to management. Students trained as managers are the ones supposed to 'enter into society' and apply their concepts and methods in order to fix what's wrong. This inevitably contributes to the re-description of the social as a form of the economic, whereby the managerial tools become much more applicable and the managerial role correspondingly more central, something which has similarly happened with entrepreneurship in general (see Hjorth, 2003).

But maybe - we would like to suggest - social entrepreneurship can surprise the field of entrepreneurship when the latter moves into that delightful position of 'letting itself be surprised'. By turning to unknown territories and groundings and by embracing the indefiniteness of social entrepreneurship, the field of entrepreneurship can open itself to new and innovative questions and angles - in short to the entrepreneurial. In this sense we would like to point to Michel de Certeau's (1984) ideas of tactics and tacticians as describing well how the field of entrepreneurship might move: always by creating surprising uses of the dominant conceptions of society and by not hanging on to what it wins, by not being defined by its trophies but rather, precisely to the contrary, by being perenially changed by the latest chapter in its emerging story. This book thus lets itself be seduced by 'the other' of social entrepreneurship and seeks to take its chances to redirect and sculpt the current attention being paid to social entrepreneurship in a direction where 'the social' of social entrepreneurship is the 'strange attractor' and the 'virtuality to be actualized' that focuses and innovates our thinking. Especially, with this book, we want to accentuate the point that the whole connection between entrepreneurship and social change needs to be seen in a broader and more critical light. Entrepreneurship joins here a complex discussion on welfare, social justice, civic society and the role of government that has been taking place for a longer time than the current hype indicates, that is, it doesn't start with management awaiting the economization of society that allows for the subsequent managerialization of solutions instrumental to the 'enterprising' new way forward. We believe this requires a little reservation to claim the main seat at the table of social welfare and civil society discussions. That social entrepreneurship is seen as the newest option does not come at all as surprise (see Dey in this volume), since it coincides with, and is an exponent of, the rise of the enterprise discourse (Hjorth, 2003). However, the current literature on social entrepreneurship has neglected any discussion of enterprising discourse and instead proposed social entrepreneurship as an all-encompassing solution at a moment where faith in the more traditional models of non-profit, governmental and voluntary solutions is waning (see Dey, 2006). The chapters in the first part of this book will try to examine social entrepreneurship in a critical light and stretch the discussion into its societal and political parameters, going 
beyond the alignment of social values with: (the recognition of) entrepreneurial opportunities (Dees, 1998), the making of the citizen sector as competitive as business (Drayton, 2002), and the marketization of the non-profit sector (Eikenberry and Kluver, 2004). Rather than turning to a business framework, social entrepreneurship offers a chance to also theoretically innovate the concept of entrepreneurship by examining its own sociality and starting to explore the various social theories that the metaphor of earth instigates us to.

\section{THE EARTH AND (UN)GROUNDING ENTREPRENEURSHIP}

Let us think entrepreneurship through the image of a machine, trusting that, in doing so we are aided in bringing entrepreneurship beyond subjectivity or any organizing centre (for example, an institutionally fixed empirical 'foundation'). Imagine that entrepreneurship is nothing more than the connections and productions it makes; it is what it does (Colebrook, 2002, p. 55). Deleuze's use of the concept of machine, towards which we now are leaning, is unconventional. Take the bicycle. It has no end or intention. It works only when connected to another machine, such as the human body. The production of these two machines can only be achieved through connection: the human body becomes a cyclist and the bicycle becomes a vehicle. However, Deleuze extends this understanding to all life: 'there is no aspect of life that is not machinic; all life only works and is insofar as it connects with some other machine' (Colebrook, 2002, p. 56). A machine has no home or ground, but is in a constant process of deterritorialization - or, in other words, it is constantly becoming other than itself, brought beyond the limits of what it presently is taken to be.

This book tries to deterritorialize social entrepreneurship to show how it is first of all free from any single origin and that it is performed by a plurality of collective assemblages, temporarily ordered in social institutions, but always transformable in forming new 'social machines'. Such machines continuously extend experience through imagination. A social territory can be seen as a set of social and cultural presuppositions operating as contexts for statements and practices. A thought's territory is expressed by conceptual personae - the figures presupposed by the concept. In the case of 'social entrepreneurship', the conceptual personae are the vaguely defined figures of managerialist thinking, philanthropist-CEOs reflecting upon 'what's wrong with society?' One would find an analogy in Descartes as the conceptual persona of the cogito, a concept whose territory is expressed by the figure of the solitary and doubting Descartes. This book would like to destabilize the seeming monopoly of this persona of social entrepreneurship The Thempirical studies brought s. $_{81847204424}$ 
to you in this volume instead make the entrepreneur - as a figure of a desire to create sociality, as a productive connectivity inventing practices beyond the limits of present experience to enhance the possibilities for living for citizens into the conceptual persona of social entrepreneurship. This becomes part of our attempt to affirmatively express what the social in social entrepreneurship is.

The creation of sociality, which is also the transformation of society, is of course not presocial. Rather, it is open-endedly social: 'it is social in a manner prior to the separating out of individuals and the identifiable groupings that they end up boxing themselves into (positions in gridlock). A sociality without determinate borders: "pure" sociality' (Massumi, 2002, p. 9). This sociality is before any form of interaction and before any model that we (social scientists) might use to order it. One of those forms and models launched as an ordering tool for certain forms of interaction represented as 'problem solving' by entrepreneurial means is now popularized as 'social entrepreneurship'. The characteristics of this form are what our book is about. Such characteristics are socially and culturally negotiated in different contexts. Herein lies the point of stressing contextualization. We need local images of such determination of various forms of social entrepreneurship. This should happen differently in US culture when compared to European or Swedish culture. It should happen differently within Europe as well - within specific countries, regions, cities or communities. This heterogeneity is battled in this book. We try to rescue social entrepreneurship from being incorporated in any such context-dominant determination.

If we do not assume the model of one dominant discourse to be in place, our task is instead to precisely describe and narrate contextualized concepts for this interaction-in-the-making, this relation, through which it gets socially determined. Heterogeneity in terms of descriptions and variations of contexts would therefore be a qualitative criterion of any attempt to bring studies of social entrepreneurship together in one volume.

We believe it is not farfetched to describe these various contextualizations of social entrepreneurship as expressed in the chapters of this book. This also illustrates how the emphasis on grounding and the 'earthly' in our call for the book has increased authors' sensitivity, confronted by peoples' practices of living, the mundane, the relational. Our images of entrepreneurship are here produced in a higher resolution. The belongingness of entrepreneurship to life is made more evident. Possibly as a consequence of this, even in those cases where this is not an explicit purpose of authors, the usual 'grand narratives' of entrepreneurship research (the singular, alert individual; opportunity recognition; start-up and growth models) are simply not put to use with the usual frequency. The earthly, in effect, has made authors performatively question these models or grand narratives in favour of more contextualized and

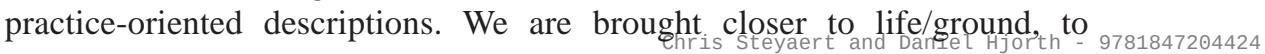


relations, to the social of entrepreneurship and to the entrepreneurial of the social.

Most often, this grounding, this sociality-focusing effect from the 'gravity' of the earthly, does not appear as a break or a revolutionary disruption of entrepreneurship as such. Rather, these new groundings are brought about as contextualizations of entrepreneurship in processes and practices previously excluded from studies of entrepreneurship (see especially part II of the present volume). There is a double movement here: firstly, there is a continuity in terms of entrepreneurship multiplying in different contexts and connections with other disciplines and other practices; and secondly, there is, in this multiplication, also a disruption of the continuity of the history of entrepreneurship. The promise of one paradigm or of stabilized definitions is not nurtured by these studies. Rather the book affects us as an event in the sense of 'something that allows time to take off on a new path' (Colebrook, 2002, p. 57). It provides new lines of flight for entrepreneurship, new ways in which it is brought beyond its present limits. Again we might describe this freeing of the event of entrepreneurship from its actual origins as a 'deterritorialization' of entrepreneurship. This book brings us examples in which the becoming of entrepreneurship 'escapes or detaches from its original territory' (Colebrook, 2002, p. 59). The academic discourse on entrepreneurship is thus multiplied and deterritorialized/ungrounded in this book, especially so in part I.

We have, however, also presented - especially in part II - examples of how the becoming of entrepreneurship is re-territorialized. Bodies of thought and practice are brought together (such as when Kathryn Campbell makes entrepreneurship meet discourses on sustainability and care-of-the-self practices in Chapter 8) and create events beyond those bodies. Entrepreneurship is reterritorialized in new languages, new cultures, new practices and new socialities. These re-territorializations of entrepreneurship produce novel ways of making sense of the entrepreneurial: Fletcher and Watson (Chapter 7) bring us inside a community-building work, an urban-rural movement forming the context of entrepreneurial possibilities with consequences for how people organise their daily lives both as entrepreneurs and as inhabitants of rural areas. Campbell's chapter shows us how self- and world-making go together in the invention of everyday practices in their minute details, just as these are related to global issues of immense importance. She indicates how the personal and the global are already first social through friendships, family and community. Johannisson and Wigren, in Chapter 9, tell us about an ungrounding-in-themaking, namely the story of how the self-reviewing capacity of the community of Gnosjö is about to lose its local force and escape into a master narrative. Grounding this again seems to require a living story of the present rather than a grand narrative of the past - a collective identity grounded in action and not simply carried as a brand. Lindgren and Packendorff, in in $_{\text {Chris }}$ Seyaert and Danlel Hjorth 9784204424 
Chapter 10, show how grounding locally is a highly political process of seeking legitimacy while still maintaining one's flexibility. In a way they bring us the story of a small rural town being deterritorialized by a group of rock enthusiasts and re-territorialized as a Rock-City. Berglund further describes how the gap between productive discourses and what one can do in one's local community is handled in the self-forming practices of her entrepreneurs. From Beyes, finally, we learn how art can deterritorialize what we took for granted and reterritorialize this in surprising ways. This creates effects and this in turn takes us back and allows us to start thinking from a new ground.

In effect, this multiplying of entrepreneurship and contexts for entrepreneurship, which is one important contribution of this book, democratizes entrepreneurship by multiplying the practices through which becomingentrepreneurship happens in society. We believe that it is in this sense that we could claim that this book is also entrepreneurial, in that it manifests an active thinking that affirms the de- and re-territorializations of entrepreneurship and, by doing this, prepares both the study of entrepreneurship and the study of society to become affected by entrepreneurship, something necessarily related to society's capacity to act entrepreneurially.

\section{CONCEPTUALIZING SOCIAL ENTREPRENEURSHIP}

The first section of this book - entitled Concepts of Social Entrepreneurship starts with a chapter by Richard Swedberg that encourages us to reculer pour mieux sauter and to avoid the idea that social entrepreneurship develops itself without any historical notion of the development of the thinking on entrepreneurship, so as not to reinvent the wheel. Swedberg joins the current interest in some writings of Schumpeter that have been translated from German only recently, which allow us to speak of a 'young' Schumpeter as some of his more radical ideas in Chapters 2 and 7 of the 1911 edition of his book Theorie der wirtschaftlichen Entwicklung had been heavily reduced and rewritten if not totally omitted from the later English edition of 1934 entitled The Theory of Economic Development. Swedberg undertakes a close reading of both chapters to trace what Schumpeter has to say on the relationship between entrepreneurship and both economic and social change.

The consequence of Swedberg's undertaking is twofold. Firstly, he stimulates those who participate in the study of social entrepreneurship to connect their interests to a general theory of entrepreneurship, which centers on the notion of change as a form of development 'from within' in contrast to change as adaptation 'from the outside'. These qualitatively new changes have ambivalent social consequences as they are only temporary for the entrepreneur and might be contested and envied by others. Secondly, especially the reading of 
the seventh chapter makes it clear that Schumpeter extended his dynamic understanding of change and creative destruction to society, in light of which social entrepreneurship can be understood as a form of dynamic behaviour in one of the non-economic areas of society. The current need for more elaborated theoretical developments of social entrepreneurship can thus be addressed within Schumpeter's general theory of entrepreneurship. However, Schumpeter's view on entrepreneurship emphasizes predominantly the individual role of the (social) entrepreneur instead of taking a social view on entrepreneurial processes.

To conceive of the social of entrepreneurship, Yohanan Stryjan proposes in Chapter 2 to reframe social entrepreneurship by shifting the focus from the social objectives of social enterprises to their modes of action. Using a resource perspective, he suggests focusing on the mobilization of and investment in resources over time and on defining and mustering the support of an emerging community. Looking for quasi-anthropological manifestations of entrepreneurship beyond the usual high-profile 'suspects', he illustrates the practices of cooperative enterprises in the Swedish context since the 1970s that range between welfare, social and community cooperatives. Social entrepreneurship involves the mobilizing of socially embedded resources and their conversion into (market-) convertible resources, and vice versa. The conversion, re-conversion and reproduction of resources are the practices that enact and maintain these social enterprises and show how their social elements both precede and create the social communities in which they are embedded.

Robert B. Anderson, Benson Honig and Ana Maria Peredo (Chapter 3) aim to introduce indigenous entrepreneurship as a promising research domain for the study of social entrepreneurship. They investigate the specificities of social entrepreneurship as it relates to indigenous people in a global economy, extending the (complex) interdisciplinary context of social entrepreneurship with literature on socio-economic, indigenous and community development. The life situations of indigenous people and their communities, often characterized by social disintegration, poverty and poor health, require us to investigate 'how development can be understood' and 'what the role of community can be in this'. Indigenous people, dominated and often mistreated in a geographical, political and economical sense by later inhabitants and maintaining a distinctive socio-cultural identity, see entrepreneurial activities as important vehicles to 'develop' and change their socio-economic situations and to rebuild their communities. The authors investigate three perspectives on development to see whether they are compatible with the hope and ambition of indigenous people to plan and control their own development and to 'negotiate' a constructive participation for themselves in the global economy. Besides the assimilation and dependency models, the authors argue that the contingency models represented by regulation theory can be best aligned with 
the context of indigenous peoples, as it enables an understanding of other people and cultures. This is because its central focus is on processes of social regulation which can make the role of communities and their counter-hegemonic potential in the context of alliances and relational contracts clear, as the global economy is created and sustained through localized processes where community-based entrepreneurial activities can take shape.

In Chapter 4, Ellen O'Connor focuses on what she calls 'high-profile social entrepreneurship', which represents a particular interpretation of social entrepreneurship: framed in a distinct way by elite business schools and their stakeholders, social entrepreneurship brings a market-orientation to social issues and promotes the professionalization of the non-profit and public sectors. Instead of such high-profile social entrepreneurship with its simultaneous global scope and narrow vision, O'Connor suggests a different articulation of social entrepreneurship that focuses on the local, mundane, accidental, informal and modest, which relocates and extends this discourse from business schools and elites to communities, grass-roots organizing and local problemsolving. This opening up of the participatory platform of social entrepreneurship is illustrated in three compelling stories related to research work Ellen O'Connor did on homelessness and management history and which interweave the political, social and historical dimensions of each entrepreneurial story of social change. These stories thus expand social entrepreneurship in two directions - as social activity that is entrepreneurial in nature and as enterprise that is social in nature. This forms the social cauldron of entrepreneurship - the minutiae of persistent and emergent interactions among a multitude of players, played out through elusive social processes and social scenes. The first story looks at the so-called 'homelessness industry', which forms a complex social network with its government agencies, professional and policy-making institutions and NPO and local communities, and which was once initiated 'entrepreneurially' through social actions like activism and hunger strikes. The second case tells the story of Jane Addams and how she established - an entrepreneurial endeavour by itself - Hull House, a well known settlement house in Chicago for young female students at the beginning of the twentieth century, from which one of the greatest social movements would follow. The third case tells of the emergence of academic entrepreneurship in a broadly social light, entangled in the complexities of history between the two world wars.

In Chapter 5, Daniel Hjorth and Björn Bjerke question whether we can hold on to the overcodified term social entrepreneurship and inquire into the possibilities of the notion of public entrepreneurship both empirically and conceptually. They depart from the experiences they have had in a Swedish learning arena, where participants in different kinds of entrepreneurial projects were sharing experiences and reflecting on their own self-understandings and practices of 
how they were creating new social contexts for themselves and other citizens. These experiences of everyday entrepreneurial practices are set apart from the more general observation that the social more and more becomes an epiphenomenon of the market, turning citizens into consumers. Hjorth and Bjerke resist such consumerist understandings of these entrepreneurial initiatives. To safeguard the space of sociality and citizenship, they undertake a genealogy of the social and the citizen. On such an account, they indicate how the constitution of society and the social has targeted the conscious consumer as a member of an enterprising society, and look for alternative routes for conceiving the social. To inscribe (social) entrepreneurship into a process of social change, a move from the social to the public, and from the consumer to the citizen, is suggested. Interpreting the learning arena experiences of the participants within this new framework, they point out that these initiatives can be conceptualized as citizen-driven, where the creation of the social outside an economic logic is what makes a difference for the participants' everyday practices. Hjorth and Bjerke propose to affirm the political and ethical possibilities of social entrepreneurship where the social becomes shaped in new ways through these intensive and collective forms of public entrepreneurship. Where people are invited to practice creative citizenship and to bring collectivity into the public space, the social is understood as collective investments in desiring images that are transformed in public spaces where creating and experimenting - and learning and resisting - can take place. Social entrepreneurship conceived in and through public spaces might be seen as a form of 'citizenship-becoming-public-entrepreneurship' that can emphasize the ethical and political effects of social change brought about by social - read public - entrepreneurs.

Pascal Dey, in Chapter 6, wonders why the academic literature creates a univocally positive image of social entrepreneurship. Taking a rhetorical view on social science, he looks into how the scholarly community has appropriated the term 'social entrepreneurship', how certain constructions become favoured while others are elided. Reading how social entrepreneurship is constructed in academic texts, Dey brings forward traces of a multiplicity of discourses, such as the ones of 'medical treatment' making 'patients' at once dependent and accountable, of 'progressive development' rejecting the status quo and reifying external pressures, of an 'economy' that is at once global, anti-bureacratic and universal, of 'technical rationality' that privileges measurement, scientific method and the normal and of 'individualism' that makes social entrepreneurs at once morally superior, supernatural individuals and male. Taking social entrepreneurship as an indeterminate sign, core tensions and power struggles can be located and new language games might be imagined. Dey's deconstructive reading shows how the writing on social entrepreneurship favours an economic calculus and technical rationality, medical dependency and ${ }_{\text {chry }}$ steyaert and Daniel Horth 9781847204424 
'progressive' development; in short it follows the 'programme' of entrepreneurship research in general. This becomes interpreted in relation to what Lyotard has called the principle of performativity, keeping social entrepreneurship measurable, programmable, predictable and instrumental. Returning to an open meaning of the social and thinking of an ethics of social entrepreneurship, Dey argues that there is no a priori judgment of social entrepreneurship as socially and morally possible; rather it appears vital to imagine social entrepreneurship as an act that is addressed unconditionally to the genuine other. As part of a prospective agenda of social entrepreneurship, Dey suggests (in Spivak's terms) a 'practical politics of the open end', where small narratives evoke the multiple possibilities of the undecidable and open other avenues of social entrepreneurship. A series of such stories that attempt this follows in the second section bringing various contexts of social change.

\section{CONTEXTUALIZING SOCIAL CHANGE}

The second section of this book - Contexts of Social Change - takes us to the not-so-obvious places of entrepreneurship. Bound together by their attention to - and sensitivity before - shifting locations, places and the spatiality of entrepreneurial processes, these chapters contextualize entrepreneurship through their relational-societal constitution in various collective bodies as social change.

The section opens with a chapter by Denise Fletcher and Tony Watson. They bring us stories of urban-rural shifters, people who, for a variety of reasons, move from their urban homes to settle in rural areas and do so through different ways of living. In studying people developing rural areas (the community of Kerston, UK) into attractive places for living and those making the urban-rural shift, Fletcher and Watson are interested in the meanings that these people attach to their lives and the moves they have made. They concentrate on how such an urban-rural move facilitates market opportunities in rural communities and how such opportunities, when actualized, open new lines of flight through which social change takes place. Following an entrepreneurdeveloper (Eddie Newhall), we learn from Fletcher and Watson's conceptualization of the entrepreneur-client relationality how social change processes transform the Kerston district as well as the people involved in this social becoming. Using the concept of (shifting) life orientations, the authors thicken their story of the interrelated nature of social change and entrepreneurship.

In Chapter 8, Kathryn Campbell argues for the expansion of the entrepreneurial debate to contemplate the merits of localized, small-scale, non-heroic enterprise which she studies in Africa as much as in rural Canada, in our times as much as in the early nineteenth century. Her text assembles or - in her own 
words - 'quilts' together three stories, differently told, of women who invent the 'business' of living through gardening - a healing process that connects their selves, their work lives and the communities they take part in. Interweaving ecofeminism, bioregionalism and the survival subsistence perspective, the concept of social change she envisions is what is called 'grounded entrepreneurship' that aims at a sustainable entrepreneurial ethic and that recognizes a life-sustaining dependence on 'Mother Earth'. Campbell's stories manifest how change starts at home and how women gardeners - living from and with the land - become expert guides for grounded entrepreneurship.

Bengt Johannisson and Caroline Wigren set out to 'rock' the stable story of an entrepreneurial local community - Gnosjö, Sweden - known for its historically (re)produced hotbed of entrepreneurship. Their sociality in focus is the interrelated individual and collective identity constructions in the context of a local community - a community dominated by multi-generational family businesses with modest growth ambitions (as Johannisson and Wigren put it). Approaching this industrial district as one always celebrating the 'good old times' (in the authors' words, an imprisoning curse) rather than self-reflexively developing alternative futures, the authors are concerned with the need for a remaking of the community's identity. Revisiting Gnosjö as ethnographers and readers of their own previous texts, Johannisson and Wigren trace forces that would counteract their initial description of an industrial district trapped in its historically mediated and outdated self-image as successful, and thereby provide seeds for reconstructing entrepreneurship and social change. They bring us stories of 'participants' in 'social worlds', and through putting these concepts to use, make it possible to connect the future story of Gnosjö with forces guiding a way out of the present 'social prison', typified in the complexities of the 'master narrative' of the 'spirit of Gnosjö'. 'Outsiders' to the dominant social world of Gnosjö provide challenges to the 'normal' by thriving on ambiguity, and Johannisson and Wigren show how the tension this generates for 'insiders' can be creative in crafting an alternative collective identity.

Monica Lindgren and Johann Packendorff intensify our relationship (from Chapter 10) with boundary work in relation to the local-cultural context. The story of the small town of Hultsfred, Sweden, and the Rock Festival is one of deviating and belonging, a story of people constructing boundaries in order to stretch and test them, a story of entrepreneurship from a relationalconstructionist viewpoint. The authors bring us narratives of punk-rebelsbecoming-entrepreneurs and rock-festival-becoming-town-development centered on a national music centre, business incubators, university education in music management and so on. Lindgren and Packendorff, while telling the story of Hultsfred, do not leave out the stories of organizers-becoming-parents 
and informal-networking-becoming-professional-board: processes that enrich the thick description of this case of entrepreneurship as social change. Struggling with the tensions between a nonconformist rock music lifestyle and the need for belonging to local, regional, national and international communities, change is propelled by boundary work resulting in a continued responsibility and desire for developing Hultsfred as town, region, national centre and rock festival. This boundary-work shares similarities with Johannisson and Wigren's story in that the rock festival people continuously need to work on changing the way the citizens of Hultsfred view themselves and their community in order to develop the festival. Lindgren and Packendorff do not leave us with a model or some packaged solutions, but, on the contrary, show how entrepreneurship as boundary work is a continuous, slow, and ongoing endeavour of (in the authors' words) balancing sensibility and belonging for the sake of changing practices against strangeness and deviation for the sake of redefining how the world is seen and handled.

Karin Berglund discusses in Chapter 11 how two entrepreneurs draw on discourses in order to make space for their entrepreneurial identities. She provides us with close-up stories of becoming-entrepreneur. In the context of a local 'catastrophe' - 1,500 people made redundant entering into the state of 'job-seekers' - timed with a large EU-project promoting entrepreneurship in minority groups, we get to follow Lena and Sara who are about to start their own businesses. Berglund's two-year ethnographic study of these women develops into a journey where the women relate to the equality and enterprise discourses prevalent in the region in quite different ways, while simultaneously changing their lives and identities in the processes of becoming entrepreneurs. In this interplay between identity and discourse, the different stories of these two entrepreneurs and their fashioning of entrepreneurial identities unfold. In the context of identity formation, the process of becomingentrepreneur, Berglund concludes, should be seen as a complex collection of processes taking place in different arenas of life. Social change is here the result both of discourses affecting a community and its self-descriptions as well as how these two women fashion their identities as entrepreneurs. But the possibilities of these discourses (equality and enterprise) are also shaped by the social change described locally as 'the catastrophe' (large-scale sudden unemployment). Berglund's case brings to the fore how entrepreneurship is made visible in society, and she asks us to consider the relationship between these forms of visibility and the ways in which entrepreneurship is practiced.

Entrepreneurial discourse has entered city life and requires a critical analysis of its effects: what spaces are produced and excluded? What social realities created? To make such a critical analysis, Timon Beyes enters a small theater in Berlin and watches a play by the German playwright Pollesch, entitled City as Prey that forms its own entrepreneurial genre of theater discourse. 
Watching and reading this play allows him simultaneously to point at the dominant discourse of enterprise that literally encloses the life of citizens and to look for alternative spaces. In a first, apocalyptic, reading of the play, it seems there is no escaping the hegemonic reign of enterprise discourse as city space is produced and controlled through this master discourse. A second, exemplary, reading attempts to provide a social and political critique, pointing out that the reproduction of grand narratives can become interwoven with alternatives developed through heterotopic spaces. Not in the least the artistic space itself can form a heterotopia that intervenes and might alter dominant conceptions of the so-called entrepreneurial city, suggesting how entrepreneurship in a different mode can bring vitality and creativity to cities: urban spaces may then be regarded as potential 'lived spaces' or as heterotopias. Heterotopic sites and spaces are where social change and transformation are constituted through entrepreneurial activities. This double reading of Beyes, creating a presence of difference, implies also an aesthetic form of writing that at once makes visible and complex the things that might 'escape' the attention of the audience of Pollesch's play in the theater or that might be taken for granted in the play of urban entrepreneurialism we all take part in. 